\title{
Antibacterial and Cytotoxic Effects of Moringa oleifera (Moringa) and Azadirachta indica (Neem) Methanolic Extracts against Strains of Enterococcus faecalis
}

\author{
Lucía Arévalo-Híjar, ${ }^{1}$ Miguel Ángel Aguilar-Luis $\mathbb{D}^{\mathrm{D}}{ }^{2,3}$ Stefany Caballero-García, ${ }^{1}$ \\ Néstor Gonzáles-Soto, ${ }^{1}$ and Juana Del Valle-Mendoza $\mathbb{D}^{2,3}$ \\ ${ }^{1}$ School of Odontology, Health Sciences Faculty, Universidad Peruana de Ciencias Aplicadas-UPC, Lima, Peru \\ ${ }^{2}$ Research Center and Innovation of the Faculty of Health Sciences, Universidad Peruana de Ciencias Aplicadas, \\ Av. San Marcos cdra 2, Cedros de Villa, Lima, Peru \\ ${ }^{3}$ Institute of Nutritional Research (IIN), 1885 La Molina Ave., Lima 12, Peru
}

Correspondence should be addressed to Juana Del Valle-Mendoza; joana.del.valle@gmail.com

Received 13 June 2018; Accepted 26 August 2018; Published 25 September 2018

Academic Editor: Louis M. Lin

Copyright (c) 2018 Lucía Arévalo-Híjar et al. This is an open access article distributed under the Creative Commons Attribution License, which permits unrestricted use, distribution, and reproduction in any medium, provided the original work is properly cited.

\begin{abstract}
Objective. To evaluate antibacterial and cytotoxic effect of 2 methanolic extracts of Azadirachta indica and Moringa oleifera against strains of Enterococcus faecalis (ATCC 29212) in vitro. Methods. The methanolic extracts of Azadirachta indica and Moringa oleifera were prepared in vitro. The antibacterial effect of the extracts against Enterococcus faecalis was evaluated using the agar diffusion technique. The minimum inhibitory concentration (MIC) was determined using the microdilution method and the cytotoxicity using the cellular line MDCK. Results. The methanolic extract with the most antibacterial effect during the first 24 and 48 hours against Enterococcus faecalis was Moringa oleifera, evidencing a growth inhibition zone of $35.5 \pm 1.05$ and $44.83 \pm 0.98$, respectively. The MIC for both extracts was $75 \mu \mathrm{g} / \mathrm{ml}$. The bactericidal effect of the Azadirachta indica extract was found at a concentration of $25 \mu \mathrm{g} / \mathrm{ml}$ and a concentration of $75 \mu \mathrm{g} / \mathrm{ml}$ for Moringa extract. Conclusions. In conclusion, we demonstrated that the methanolic extract of Azadirachta indica and Moringa oleifera both have an antibacterial effect against Enterococcus faecalis strains during the first 24 and 48 hours. None of the extracts exhibited toxicity against the cell lines under low concentrations.
\end{abstract}

\section{Introduction}

One of the main objectives of endodontics is root canal disinfection, mainly associated with the colonization of anaerobic bacteria. There are endodontic treatments that fail due to a complex root canal anatomy or antibiotic resistance of some bacterial families, with Enterococcus faecalis being the most resistant bacteria reported [1-6].

Various antibacterial agents have been previously studied, and they can be obtained from natural sources or synthetic agents [7]. Furthermore, recent studies have reported the pharmacological properties and high medicinal value of a myriad of natural extracts. Some of these products, however, have been used empirically, leaving aside the study and determination of its properties [8].

The contemporary field of phytotherapy focuses on the study of plants and its pharmacological properties to treat diseases. Azadirachta indica also known as neem and Moringa oleifera also known as moringa are both native Indian trees known for their high medicinal values due to their curative properties [9-15]. A. indica has analgesic, antifungal, and antibacterial properties and has therefore been used as treatment for gastrointestinal ailments, mouth hygiene, and certain chronic diseases such as diabetes, high blood pressure, and dyslipidemia [16-19]. On the other hand, M. oleifera has been reported to have antiviral, 
antioxidant, antisclerotic, antibacterial, and antiinflammatory properties. It has been used as treatment for malaria, malnutrition, colon cancer, and myeloma [20].

Even though these plants have been studied to treat the previously mentioned ailments, no research evaluates if time is directly correlated with the antibacterial effect of $A$. indica against $E$. faecalis. On the other hand, there has yet to be any research on the antibacterial effect of $M$. oleifera or its cytotoxicity as a root canal disinfectant.

The objective of this study was to evaluate the antibacterial and cytotoxic properties of methanolic extracts of A. indica and $M$. oleifera against some Enterococcus faecalis strains (ATCC 29212) in vitro.

\section{Materials and Methods}

2.1. Sample. The sample size was determined with a formula of comparative means using the statistical software Stata ${ }^{\circledR}$ version 12.0. A confidence interval of $95 \%$ was considered, and a power of $80 \%$ was used. The mean and standard deviation parameters for a group were obtained using a pilot test that was previously run. Finally, a sample of 6 wells per group was established.

2.2. Extract Preparation. Fresh A. indica leafs and pulverized M. oleifera leafs were obtained from a naturist shop. Both were free of impurities and had a sanitary registry. These products were placed in different containers and were treated with absolute methanol (1:2 weight/volume) to be later stored at room temperature for 10 days without sunlight exposure. The solutions were filtered through Whatman paper no. 4 and placed in labeled tubes. A rotatory evaporator was then used at $50^{\circ} \mathrm{C}$ to separate the methanol by distillation to finally obtain a pure extract. The extracts were stored at $4^{\circ} \mathrm{C}$ until use.

2.3. Bacterial Cultures. Enterococcus faecalis ATCC 29212 was obtained from GenLab Laboratory in Peru, a representative of MicroBiologics Laboratory (USA). The bacteria were cultured in agar BHI (brain heart infusion) in anaerobic conditions at $37^{\circ} \mathrm{C}$ for 72 hours. 3 to 4 colonies were then isolated and later inoculated in $3 \mathrm{~mL}$ of a BHI broth under the same conditions previously mentioned. The cultures were then diluted in a sterile saline solution to reach a McFarland scale density of 0.5 , which approximately estimates a concentration of $1.5 \times 10^{8} \mathrm{CFU} / \mathrm{mL}$.

2.4. Antimicrobial Activity Evaluation. Antimicrobial activity evaluation was achieved using the well diffusion method [21]. BHI agar was prepared and autoclaved at $121^{\circ} \mathrm{C}$ for 15 minutes. The agar was left to cool, and then the previously prepared bacterial suspension was inoculated. Finally, we proceeded to add the agar to sterile petri dishes. A sterile cork borer was used to punch $9 \mathrm{~mm}$ holes on the agar plate which were then filled with $1000 \mathrm{~mL}$ of each methanolic extract. In addition, $2 \%$ chlorhexidine was used as the positive control and $1 \times$ saline solution as the negative control. The agar plates were incubated at $37^{\circ} \mathrm{C}$, and the diameters of the inhibition growth zones were measured during the first 24 and 48 hours in millimeters with a vernier caliper.

\subsection{Determination of the Minimum Inhibitory Concentration} (MIC). The minimum inhibitory concentration was determined using the microdilution method described by Gupta and Negi [22]. Each methanolic extract underwent serial dilutions (1/2), and each solution was added to the wells in the petri dishes with concentrations ranging from 1.56 to $75 \mu \mathrm{g} / \mathrm{ml}$. In addition, $2 \%$ chlorhexidine was used as the positive control and $1 \times$ saline solution as the negative control. The plates were incubated under anaerobic conditions at $37^{\circ} \mathrm{C}$ for 24 hours. The minimum inhibitory concentration was considered as the minimum concentration of the extract that inhibited bacterial growth.

\subsection{Determination of the Minimum Bactericidal Concentra-} tion $(M B C)$. The methanolic extract dilutions were added into each well of a 96-well microtiter plate, and then the bacterial suspension was inoculated. The plate was incubated at $37^{\circ} \mathrm{C}$ for 24 hours. In order to determine the minimum bactericidal concentration (MBC), aliquots were pipetted out of each well and seeded onto the agar. The sample petri dishes were incubated under anaerobic conditions at $37^{\circ} \mathrm{C}$ for 24 hours. The minimum bactericidal concentration is defined as the minimum concentration required to inhibit any bacterial growth.

2.7. Cytotoxicity Evaluation. Cytotoxicity was evaluated by means of a colorimetric assay based on the reduction of MTT by mitochondrial enzymes [23]. A 96-well microtiter plate was used to culture $1 \times 10^{4}$ cells per well. The plate was then incubated at $37^{\circ} \mathrm{C}$ in a humid atmosphere of $5 \% \mathrm{CO}_{2}$ for 24 hours. Subsequently, we proceeded to pipette the methanolic extracts Azadirachta indica (neem) and $M$. oleifera (moringa) with concentrations ranging from 0 to $100 \mu \mathrm{g} / \mathrm{mL}$ onto the monocellular layer. Each concentration assay had a positive control for cellular viability (culture medium without any extracts). The plates were incubated at $37^{\circ} \mathrm{C}$ for 6 days, and the morphology of the cells was surveilled daily. The cytotoxic concentration $50\left(\mathrm{CC}_{50}\right)$ is defined as the concentration of a substance required to decrease cellular viability by $50 \%$.

Twenty microliters of MTT solution ( $3 \mathrm{mg} / \mathrm{ml}$ in PBS 1X) was added into each well and then left incubating for 3 hours. The medium was carefully removed to obtain the formazan crystals which were then diluted with $200 \mu \mathrm{L}$ of DMSO (dimethyl sulfoxide). In order to determine cellular viability, a microplate photometer was used to measure and compare the absorbance of the treated cultures against the nontreated culture. The results were analysed with the computer software Pharm/PCS. The monolayers were observed under the microscope to evaluate any morphological changes. 
TABLE 1: In vitro antibacterial effect of $2 \%$ chlorhexidine and the methanolic extracts of Moringa oleifera and Azadirachta indica against Enterococcus faecalis during the first 24 and 48 hours.

\begin{tabular}{lcccccrr}
\hline \multirow{2}{*}{ Time } & \multirow{2}{*}{ Extracts } & \multicolumn{5}{c}{ Growth inhibition zone (mm) } \\
& & Mean & Standard deviation & Median & Minimum & Maximum & $p^{*}$ \\
\hline \multirow{3}{*}{24 hours } & Azadirachta indica & 33.16 & 0.75 & 33.00 & 32.00 & 34.00 \\
& Moringa oleifera & 35.50 & 1.05 & 35.50 & 34.00 & 37.00 & $<0.01$ \\
& Chlorhexidine & 19.16 & 1.33 & 20.00 & 17.00 & 20.00 & 42.00 \\
\multirow{3}{*}{48 hours } & Azadirachta indica & 39.83 & 3.37 & 42.00 & 35.00 & 46.00 \\
& Moringa oleifera & 44.83 & 0.98 & 44.50 & 44.00 & 46.00 \\
& Chlorhexidine & 27.00 & 1.09 & 27.00 & 26.00 & 29.00 \\
\hline
\end{tabular}

${ }^{*}$ Kruskal-Wallis test.

2.8. Statistical Analysis. The antibacterial effect was registered in millimeters $(\mathrm{mm})$. It was analysed by means of a nonparametric test, Kruskal-Wallis, with a statistical significance level of $5 \%$ for the comparison between A. indica, M. oleifera, and chlorhexidine. Data were analysed using the statistical package Stata ${ }^{\circledR}$ version 12.0.

\section{Results}

3.1. Antimicrobial Activity of the Natural Extracts. After the first 24 hours, the methanolic $A$. indica extract generated a growth inhibition zone of $33.16 \mathrm{~mm}$ and the extract of $M$. oleifera generated a $35.5 \mathrm{~mm}$ zone. At 48 hours, the growth inhibition zones were $38.83 \mathrm{~mm}$ and $44.83 \mathrm{~mm}$, respectively. The methanolic extract of $M$. oleifera had a greater antibacterial effect in comparison with chlorhexidine (control group) and the methanolic extract of $A$. indica. Furthermore, statistically significant differences were found for both groups at 24 and 48 hours $(p<0.01)$ (Table 1$)$.

3.2. $M I C, M B C$, and Bacteriostatic Effect of $A$. indica and $M$. oleifera Extracts. The MIC of both the methanolic extracts, A. indica and $M$. oleifera, was $75 \mu \mathrm{g} / \mathrm{ml}$, demonstrating a bacteriostatic concentration up to this value.

Additionally, the bactericidal concentrations for A. indica and $M$. oleifera were $25 \mu \mathrm{g} / \mathrm{ml}$ and $75 \mu \mathrm{g} / \mathrm{ml}$, respectively (Table 2).

3.3. Cytotoxicity of the Methanolic Extracts of $A$. indica and M. oleifera. The results indicate that the methanolic extracts of $A$. indica and $M$. oleifera inhibit $50 \%$ of cellular viability $\left(\mathrm{CC}_{50}\right)$ at a concentration of $70 \mu \mathrm{g} / \mathrm{ml}$. Furthermore, none of the extracts produced any adverse effects on the MDCK cellular lines at low concentrations. We observed an indirect correlation between the concentration and cellular viability (Figure 1).

\section{Discussion}

There are many different types of endodontic infections described. One of them is the persistent root canal infections for which the highly antibiotic-resistant Enterococcus faecalis is the main etiologic agent, even amongst patients previously treated for this condition [2]. The pathogenicity of these bacteria includes its capacity to penetrate dentinal
TABle 2: Bacteriostatic (MIC) and bactericidal (MBC) of $2 \%$ chlorhexidine and methanolic extracts of Moringa oleifera and Azadirachta indica against Enterococcus faecalis strains.

\begin{tabular}{lccc}
\hline $\begin{array}{l}\text { Concentrations } \\
(\mu \mathrm{g} / \mathrm{ml})\end{array}$ & $\begin{array}{c}\text { Study groups } \\
\text { indica }\end{array}$ & $\begin{array}{c}\text { Moringa } \\
\text { oleifera }\end{array}$ & Chlorhexidine \\
\hline 100 & - & - & - \\
75 & MIC & MIC/MBC & - \\
50 & - & - & - \\
25 & MBC & - & - \\
12.5 & - & - & MIC \\
6.25 & - & - & - \\
3.125 & - & - & MBC \\
1.56 & - & - & \\
\hline
\end{tabular}

tubules, its lack of need of other bacteria to survive, its ability to form biofilms in anaerobic and nutrient lacking conditions, and its resistance to acids and alkalis $[5,6,12]$. It is therefore necessary to study new antibacterial agents specific for this bacteria in order to achieve endodontic treatments with a higher success rate and a better prognosis for the tooth.

As a result of the well diffusion method, we were able to determine that the methanolic extracts for $A$. indica and $M$. oleifera had an antibacterial effect against E. faecalis during the first 24 and 48 hours. According to Olson and Fahey, the antibacterial effect of $M$. oleifera is due to the chemical compound 4-(4'-O-acetyl- $\alpha$ - $L$-rhamnopyranosyloxy)benzylisothiocyanate, whose mechanism of action involves inhibition of essential cellular membrane enzymes [24, 25]. Moreover, Lakshmi et al. mentioned that the active compound responsible for the antibacterial efficacy of $A$. indica is azadirachtin, a cellular membrane synthesis inhibitor $[16,26]$.

We also found the MIC of the extracts and concluded that no antibacterial effect was evidenced at low concentrations. In 2013, Reyes and Fernández found the MIC of the foliar extract of $A$. indica against Staphylococcus aureus to be $35 \mu \mathrm{g} / \mathrm{ml}$ [27]. Muhammad et al. also evaluated the MIC of an aqueous extract of $M$. oleifera against $S$. aureus and found it to be $6.25 \mu \mathrm{g} / \mathrm{ml}$. This difference could be explained, given the fact that the process of maceration was 3 times the present study, extracting a greater quantity of chemical compounds of $M$. oleifera [28]. 


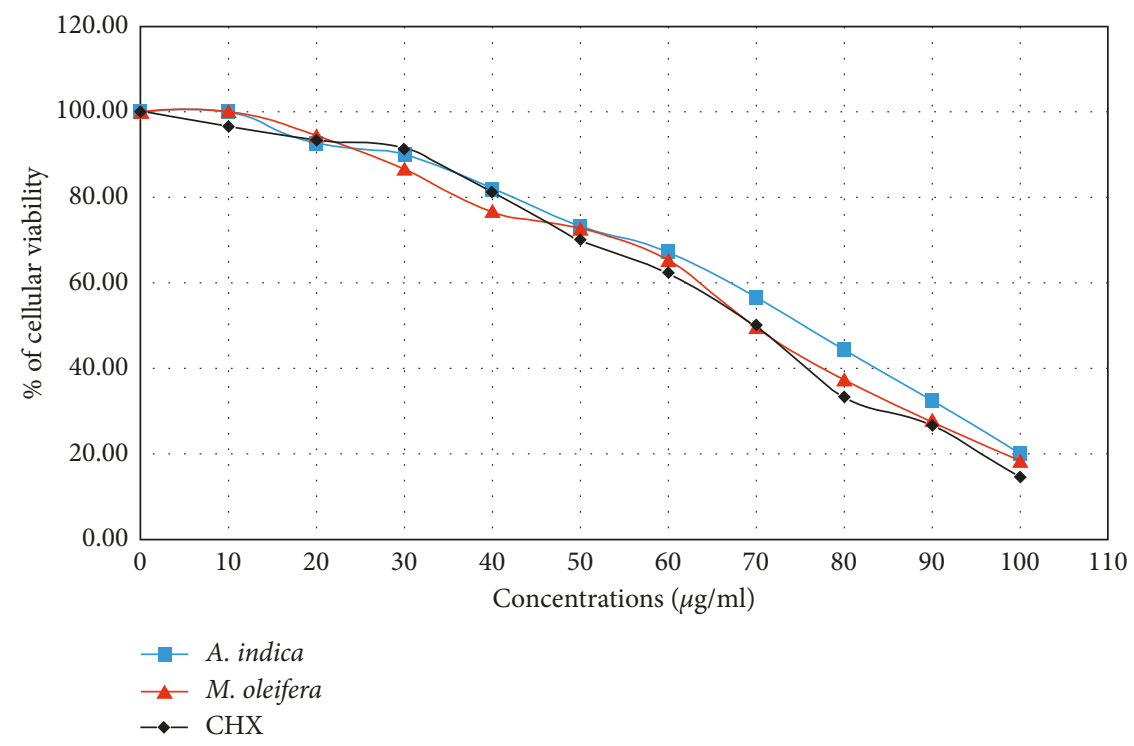

FIgURE 1: Cellular viability evaluation of Jurkat cells against the methanolic extracts of Moringa oleifera and Azadirachta indica against Enterococcus faecalis strains.

The minimum bactericidal concentration for the methanolic extract of $A$. indica was $25 \mu \mathrm{g} / \mathrm{ml}$ and $75 \mu \mathrm{g} / \mathrm{ml}$ for $M$. oleifera which leads us to conclude that at lower concentrations, $A$. indica has a greater capacity to cause cellular lysis of the bacteria in comparison with M. oleifera.

The methanolic extracts of Azadirachta indica (neem) and Moringa oleifera (moringa) did not show any cytotoxicity against the cellular line of MDCK under low concentrations. Jung evaluated the cytotoxicity of the extract of M. oleifera against a cellular line Cos-7 and demonstrated a lack of cytotoxicity even with concentrations of $600 \mathrm{mg} / \mathrm{ml}$ [20]. In 2015, Jumba et al. evaluated the cytotoxicity of the methanolic extract of $A$. indica against the cellular line VeroE6 and determined a $\mathrm{CC}_{50}$ of $149 \mu \mathrm{g} / \mathrm{ml}$. Despite the difference in these results, the study concludes that the extract stays within a manageable parameter [29].

Additionally, an in vivo study with rats showed that none of the subjects suffered any ailment after treatment with $A$. indica extract.

In conclusion, according to this study, $A$. indica and $M$. oleifera demonstrated an antibacterial effect against $E$. faecalis without any toxicity using low concentration. Therefore, they could be considered as alternative antimicrobial agents to use in the root canal therapy field in Odontology. More research is required regarding the cytotoxicity of each of its active components and also its adverse reactions.

The values that were obtained from this study show a direct correlation between the time of exposure to the extract its antibacterial effect. These results are important to continue a line of investigation in relation to fitotherapy applied to Odontology. The purpose of studies in this field is to promote the future creation of treatments based on these natural herbs considering that their use in radicular conduct treatment would lead to a better prognosis.

\section{Data Availability}

The data used to support the findings of this study are available from the corresponding author upon request.

\section{Disclosure}

The manuscript was presented as a thesis in https:// repositorioacademico.upc.edu.pe/handle/10757/621020.

\section{Conflicts of Interest}

On behalf of all authors, the corresponding author states that there are no conflicts of interest or funding related to this study.

\section{Acknowledgments}

The study has been supported by the Incentives for Research of the Universidad Peruana de Ciencias Aplicadas (Grant number UPC-COA24-2017) Lima, Peru.

\section{References}

[1] M. Ehsani, M. AminMarashi, E. Zabihi, M. Issazadeh, and S. Khafri, "A comparison between antibacterial activity of propolis and aloe vera on Enterococcus faecalis (an in vitro study)," International Journal of Molecular and Cellular Medicine, vol. 2, no. 3, pp. 110-116, 2013.

[2] F. Benbelaïd, A. Khadir, M. A. Abdoune, M. Bendahou, A. Muselli, and J. Costa, "Antimicrobial activity of some essential oils against oral multidrug-resistant Enterococcus faecalis in both planktonic and biofilm state," Asian Pacific Journal of Tropical Biomedicine, vol. 4, no. 6, pp. 463-472, 2014. 
[3] J. Siquiera and I. Rôças, "Clinical implications and microbiology of bacterial persistence after treatment procedures," Journal of Endodontics, vol. 34, no. 11, pp. 1291.e3-1301.e3, 2008.

[4] R. Zan, T. Alacam, I. Hubbezoglu, T. Tunc, Z. Sumer, and O. Alici, "Antibacterial efficacy of super-oxidized water on Enteroccus faecalis biofilms in root canal," Jundishapur Journal of Microbiology, vol. 9, no. 9, 2016.

[5] V. Zand, M. Lofti, M. H. Soroush, A. A. Abdollahi, M. Sadeghi, and A. Mojadadi, "Antibacterial efficacy of different concentrations of sodium hypochlorite gel and solution on Enterococcus faecalis biofilm," Iranian Endodontic Journal, vol. 11, no. 4, pp. 315-319, 2016.

[6] F. Ramezanali, S. Samimi, M. Kharazifard, and F. Afkhami, "The in vitro antibacterial efficacy of persian green tea extract as an intracanal irrigant on Enterococcus faecalis biofilm," Iranian Endodontic Journal, vol. 11, no. 4, pp. 304-308, 2016.

[7] M. Guneser, M. Akbulut, and A. Eldeniz, "Antibacterial effect of chlorhexidine-cetrimide combination, Salvia officinalis plant extract and octenidine in comparison with conventional endodontic irrigants," Dental Materials Journal, vol. 35, no. 5, pp. 736-741, 2016.

[8] V. Torres and A. Castro, "Fitoterapia," Revista de Actualización Clínica Médica, vol. 42, no. 2, pp. 2185-2129, 2014.

[9] P. Chandrappa, A. Dupper, P. Tripathi, R. Arroju, P. Sharma, and K. Sulochana, "Antimicrobial activity of herbal medicines (tulsi extract, neem extract) and chlorhexidine against Enterococcus faecalis in Endodontics: an in vitro study," Journal of International Society of Preventive \& Community Dentistry, vol. 5, no. 2, pp. 89-92, 2015.

[10] A. Leone, A. Spada, A. Battezzati, A. Schiraldi, J. Aristil, and S. Bertoli, "Cultivation, genetic, ethnopharmacology, phytochemistry and pharmacology of Moringa oleifera leaves: an overview," International Journal of Molecular Sciences, vol. 16, no. 12, pp. 12791-12835, 2015.

[11] W. Ghonmode, O. Balsaraf, V. Tambe, K. Saujanya, A. Patil, and D. Kakde, "Comparison of the antibacterial efficiency of neem leaf extracts, grape seed extracts and 3\% sodium hypoclorite against E. feacalis-an in vitro study," Journal of International Oral Health, vol. 5, no. 6, pp. 61-66, 2013.

[12] P. Babaji, K. Jaqtap, H. Lau, N. Bansal, S. Thajuraj, and P. Sondhi, "Comparative evaluation of antimicrobial effect of herbal root canal irrigants (Morinda citrifolia, Azadirachta indica, Aloe Vera) with sodium hypochlorite: an in vitro study," Journal of International Society of Preventive and Community Dentistry, vol. 6, no. 3, pp. 196-199, 2016.

[13] K. Vennila, S. Elanchezhiyan, and S. Ilavarasu, "Efficay of $10 \%$ whole Azadirachta indica (neem) chip as an adjunct to scaling and root planning in chronic periodontitis: a clinical and microbiology study," Indian Journal of Dental Research, vol. 27, no. 1, pp. 15-21, 2016.

[14] A. García, L. Bravo, G. Campos, and D. Medina, "Acción antimicrobiana de la Pterigospermia de Moringa olifera sobre los contaminantes del agua y su efecto en el $\mathrm{pH}$, turbidez y crecimiento microbiano," Revista electrónica de la Facultad de Ingeniería, vol. 3, no. 1, pp. 11-19, 2015.

[15] J. Rim, K. Ha Lee, D. Ha Shin, S. Sang, and S. Hwang, "Synergistic antimicrobial efficacy of mesoporous $\mathrm{ZnO}$ loaded with 4-( $\alpha$-L-rhamnosyloxy)-benzyl isothiocyanate isolated from the Moringa oleifera seed," Journal of General and Applied Microbiology, vol. 60, no. 6, pp. 251-255, 2014.

[16] A. Dutta and M. Kundabala, "Comparative anti-microbial efficacy of Azadirachta indica irrigant with standard endodontic irrigants: a preliminary study," Journal of Conservative Dentistry, vol. 17, no. 2, pp. 133-137, 2014.

[17] S. Chaube, T. Shrivastav, M. Tiwari, S. Prasad, A. Tripathi, and A. Pandey, "Neem (Azadirachta indica L.) leaf extract deteriorates oocyte quality by inducing ROS-mediated apoptosis in mammals," Springerplus, vol. 3, no. 1, p. 464, 2014.

[18] K. Mistry, Z. Sanghvi, G. Parmar, and S. Shah, "The antimicrobial activity of Azadirachta indica, Mimusops elengi, Tinospora cardifolia, Ocimum sanctum and 2\% chlorhexidinegluconate on common endodontic pathogens: an in vitro study," European Journal of Dentistry, vol. 8, no. 2, pp. 172177, 2014.

[19] V. Kumar and V. Navaratnam, "Neem (Azadirachta indica): prehistory to contemporary medicinal uses to humankind," Asian Pacific Journal of Tropical Biomedicine, vol. 3, no. 7, pp. 505-514, 2013.

[20] L. Jung, "Soluble extract from Moringa oleifera leaves with a new anticancer activity," PLoS One, vol. 9, no. 4, Article ID e95492, 2014.

[21] L. Ramirez and D. Marin, "Metodologías para evaluar in vitro la actividad antibacteriana de compuestos de origen vegetal," Scientia et Technica, vol. 42, pp. 263-267, 2009.

[22] S. Gupta and P. Negi, "Antibacterial activity of Indian borage (Plectranthus amboinicus Benth) leaf extracts in," Food Systems and Against Natural Microflora in Chicken Meat, vol. 54, no. 1, pp. 90-102, 2016.

[23] J. Del Valle, T. Pumarola, L. Alzamora, and L. Del Valle, "Antiviral activity of maca (Lepidium meyenii) against human influenza virus," Asian Pacific Journal of Tropical Medicine, vol. 7, no. 1, pp. 415-420, 2014.

[24] M. Olson and W. Fahey, "Moringa oleifera: un árbol multiusos para las zonas tropicales secas," Revista Mexicana de Biodiversidad, vol. 82, no. 4, pp. 1071-1082, 2011.

[25] C. Martin, G. Martín, A. García, T. Fernández, E. Hernández, and J. Puls, "Potenciales aplicaciones de Moringa oleifera. una revisión crítica," Pastos y Forrajes, vol. 36, no. 2, pp. 137-149, 2013.

[26] T. Lakshmi, V. Krishnan, R. Rajendram, and N. Madhusudhanan, "Azadirachta indica: a herbal panacea in dentistry-an update," Pharmacognosy Reviews, vol. 9, no. 17, pp. 41-44, 2015.

[27] D. Reyes and R. Fernández, "Efecto biocida in vitro del extracto foliar de Azadirachta indica en Staphylococcus sp y Pseudomonas sp," Salus, vol. 17, no. 3, pp. 34-41, 2013.

[28] A. A. Muhammad, P. Arulsevan, P. Cheah, F. Abas, and S. Fakurazi, "Evaluation of wound healing properties of bioactive aqueous fraction from Moringa oleifera Lam on experimentally induced diabetic animal model," Drug Design, Development and Therapy, vol. 10, pp. 1715-1730, 2016.

[29] B. Jumba, C. Anjili, J. Makwali et al., "Evaluation of leishmanicidal activity and cytotoxicity of Ricinus communis and Azadirachta indica extracts from western Kenya: in vitro and in vivo assays," BMC Research Notes, vol. 8, no. 1, p. 650, 2015. 


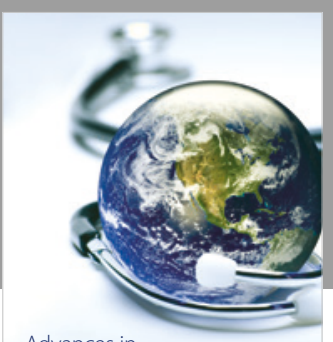

Advances in
Public Health

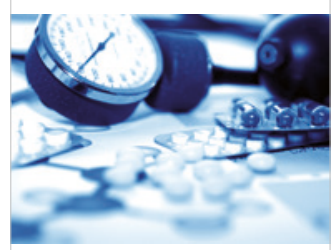

Case Reports in

Medicine

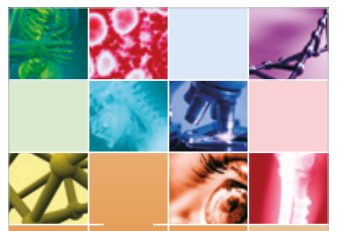

niernational Journal of

Biomaterials
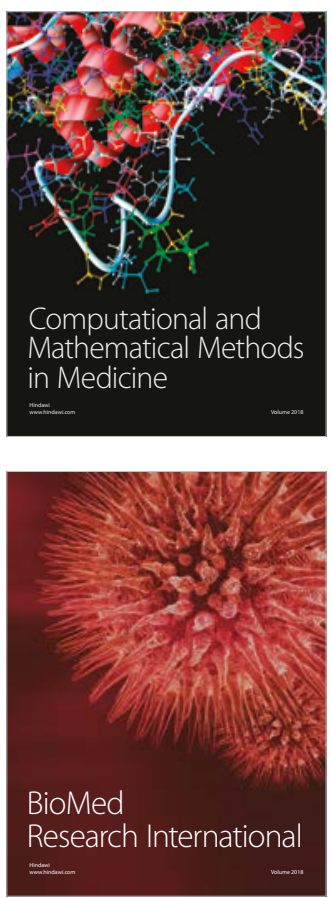

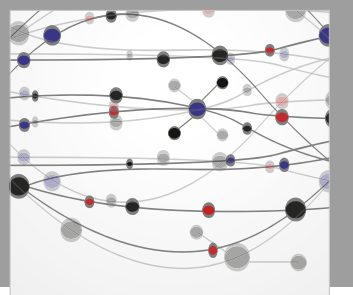

The Scientific World Journal Dentistry

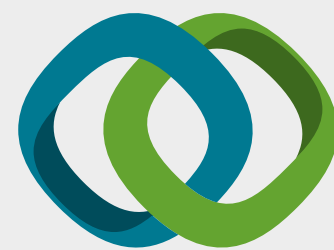

Hindawi

Submit your manuscripts at

www.hindawi.com
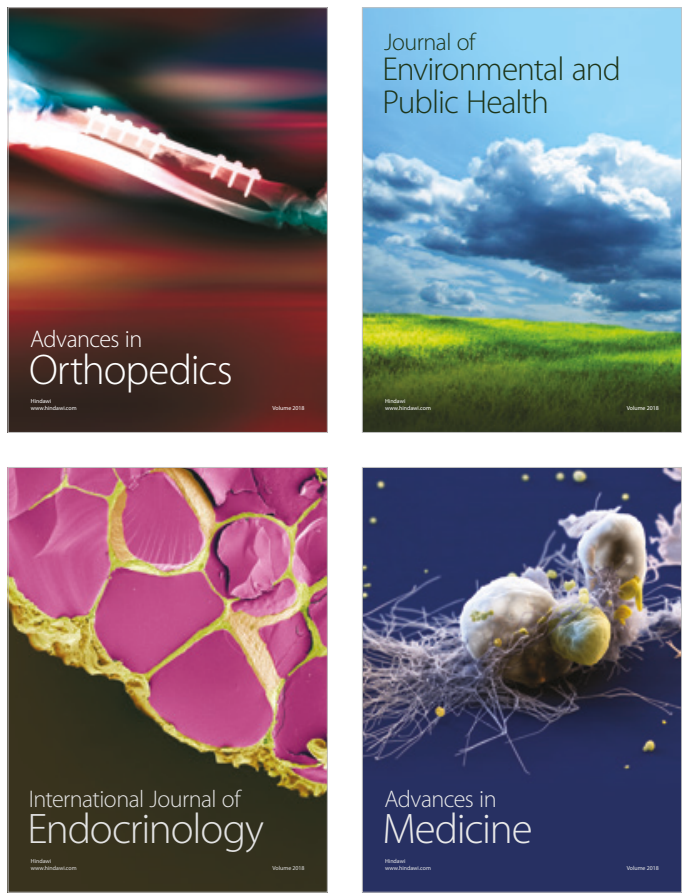
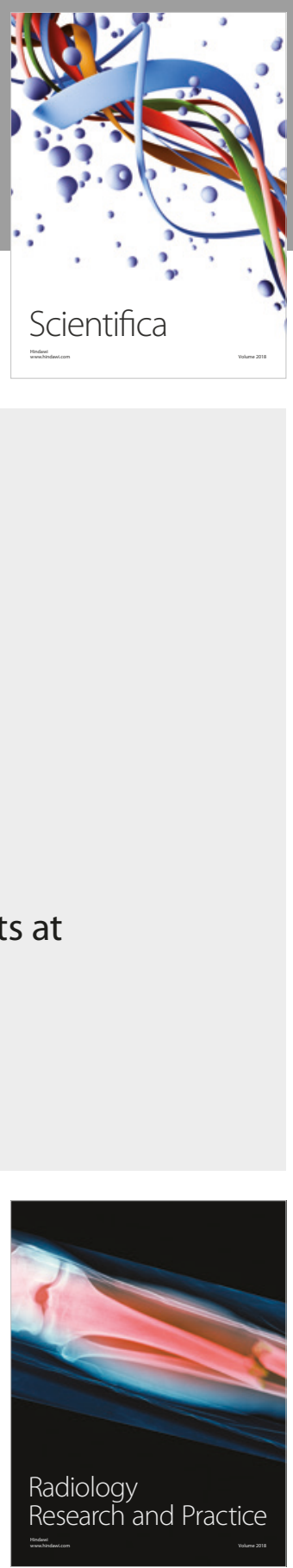

Scientifica

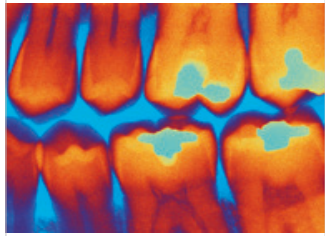

Case Reports in

Dentistry
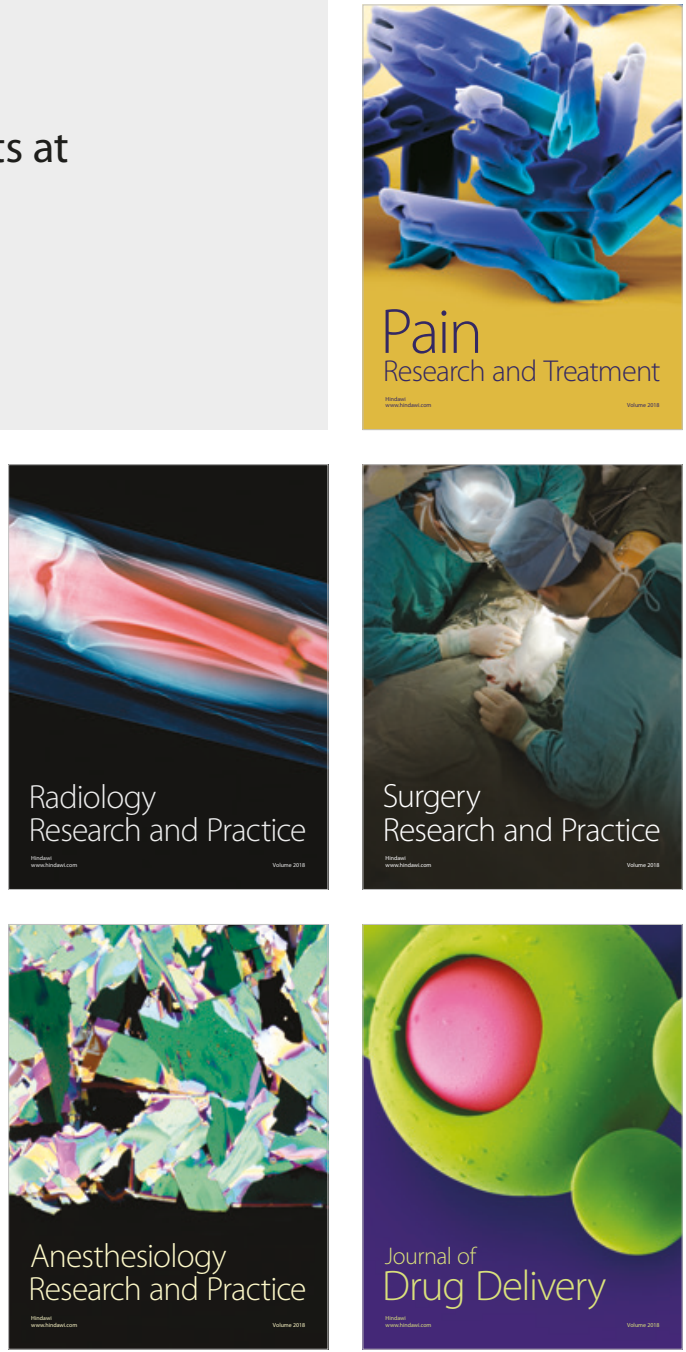